\title{
The use of the point count method for bird survey in the Atlantic forest
}

\author{
Graziele H. Volpato 1, 6; Edson V. Lopes 2; Luciana B. Mendonça 2; Roberto Boçon 1; \\ Maria V. Bisheimer ${ }^{3}$; Patrícia P. Serafini ${ }^{4} \&$ Luiz dos Anjos ${ }^{5}$
}

\author{
1 Programa de Pós-Graduação em Zoologia, Departamento de Zoologia, Universidade Federal do Paraná. \\ Caixa Postal 19020, 81531-980 Curitiba, Paraná, Brasil. \\ 2 Programa de Pós-Graduação em Ecologia de Ambientes Aquáticos Continentais, Universidade Estadual de Maringá. \\ 87020-900 Maringá, Paraná, Brasil. \\ ${ }^{3}$ Travessa da Moita Verde, 104. 88048-369 Florianópolis, Santa Catarina, Brasil. \\ ${ }^{4}$ Instituto Chico Mendes de Conservação da Biodiversidade. 88780-000 Imbituba, Santa Catarina, Brasil. \\ ${ }_{5}^{5}$ Departamento de Biologia Animal e Vegetal, Universidade Estadual de Londrina. Caixa Postal 6001, 86051-970 Londrina, \\ Paraná, Brasil. \\ ${ }^{6}$ Corresponding Author. Rua A 39, Monteverde, 36570-000 Viçosa, Minas Gerais, Brasil. E-mail: gravolpato@yahoo.com.br
}

\begin{abstract}
The point count method has been widely used in tropical forest for sampling bird communities. In the present study, we investigated if data on richness and abundance acquired using the point count method are different comparing spring/summer (breeding season) and fall/winter (non-breeding season) in three types of the Brazilian Atlantic forest. Twelve sites were sampled seasonally during one year. In general we recorded more species and individuals during the breeding seasons. However, bird communities vary seasonally among the forest types and functional groups. We demonstrate that the use of point counts in tropical forest should be adjusted considering the differences in forest types and feeding guilds.
\end{abstract}

KEY WORDS. Birds; feeding guild; seasonal changes; survey method; tropical forest.

The point count is one of most common methods to survey birds in forest ecosystems of Tropical regions. It involves mainly auditory detections of birds within fixed or unlimited radius plots (BLONDEL et al. 1970, HutTo et al. 1986). Its accuracy and efficiency are substantially influenced by observer effort, affecting information such as richness and species abundance (Rosenstock et al. 2002, BART \& Earnst 2002, BetTs et al. 2005). This method also has limitations due to variations of the bird activity during the year, which can underestimate local richness and species abundances (Whitman et al. 1997, THOMpson 2002, Antunes 2008); birds tend to be more active and more easily detected during the breeding season (usually spring and summer) than during the non-breeding season (fall and winter).

The goal of this study was to compare field data obtained by using the point count method during breeding and nonbreeding seasons in different sites of the Brazilian Atlantic forest. Basically, we investigated if data on richness and abundance obtained in spring/summer (breeding season) were different from those obtained in fall/winter (non-breeding season); our hypothesis was that those data achieved in different seasons were distinct due to an expected difference in the activity (primarily vocal activity) between the periods.

\section{MATERIAL AND METHODS}

This study was carried out in the southern portion of the Brazilian Atlantic forest from August 2003 to January 2006. There are three types of forest in the southern portion of the Brazilian Atlantic forest (see Oliveira-Filho \& FonTes 2000): seasonal semideciduous forest (SSF), mixed ombrophilous forest (MOF), and dense ombrophilous forest (DOF). Twelve study sites were sampled: four in SSF, five in MOF and three in DOF (Figs 1 and 2). The sites were selected according their size (larger than 500 ha) and history of disturbance (low disturbance); this procedure permitted a selection of representative sites of each forest type.

We used the point count method with limited distance (100 m, Hutтo et al. 1986, Biвby et al. 1992). Twelve point counts were placed in each site; each point was 200 from the other and at least $300 \mathrm{~m}$ from the forest edge. Point counts were performed in the morning, beginning with increased bird activity, and finishing around 3 hours later; the time for sampling in each point was 15 minutes, and another 15 minutes was the time necessary for the displacement of the observer and his assistant from one point to another. Six points were performed in each morning; the other six points were sampled the following day. We avoided performing point counts in days with rain and stronger wind. 

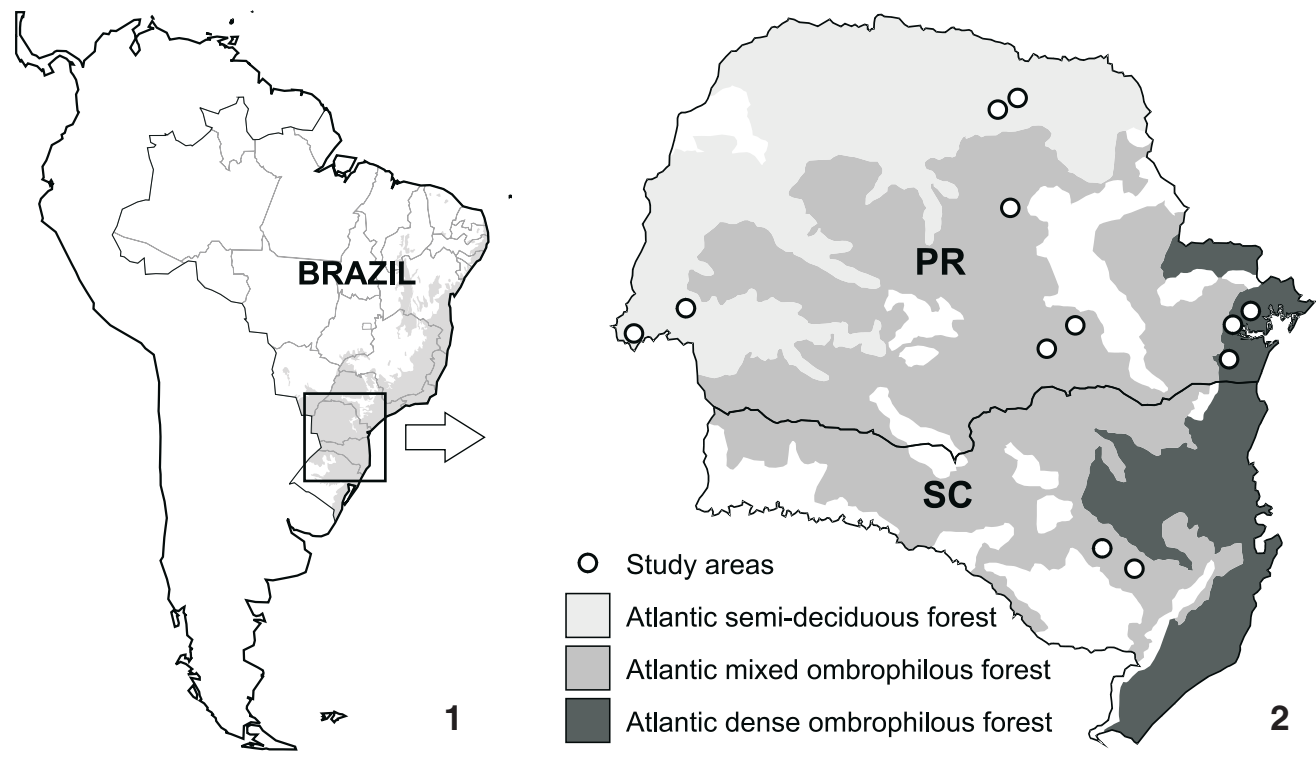

Figures 1-2. (1) The original distribution of Brazilian Atlantic Forest (gray area); the rectangle indicates the study area, (2) the studied sites (white points) in the southern portion of the Brazilian Atlantic forest, where three forest types are found; PR and SC indicates the States of Paraná and Santa Catarina respectively.

Each pair or flock of each species was counted once (one contact) during point counts. Only birds heard were recorded. There were some recordings only visually, but of species flying over the forest (e.g. vultures and herons), which were not considered in this study; their habits are not strongly related to forest. In all study sites, 12 point counts were surveyed once per annual season (spring: September-November; summer: December-February; fall: March-May; winter: July-August): this resulted a total of 192 point counts in SSF, 240 in MOF and 144 in DOF (resulting in a grand total of 576).

Bird richness and abundance were defined as the total number of species and total number of contacts respectively. In each forest type, richness and abundance were determined considering the spring/summer (breeding season) and fall/winter (non-breeding season). In addition, we analyzed variations on richness and abundance considering the functional bird groups traditionally considered in the literature with higher species numbers: frugivores, insectivores, and omnivores. The analysis based on functional groups seems more appropriate than single species or multiple lists to show modifications in ecosystems parameters, such as seasonal changes and forest structure (IONGH $\&$ VAN WEERD 2006). The Sorenson index was used to analyze the similarity between breeding and non-breeding seasons regarding to their number of species (MagurRan 1988). We used MorisitaHorn index to estimate the similarities of number of contacts among two seasons (MagurRan 1988). A Mann-Whitney test (U) was used to compare bird richness and abundance in breeding and non-breeding seasons in the three forests types and in the three functional birds groups (ZAR 1999).

\section{RESULTS}

A total of 248 bird species were recorded in the twelve sites sampled; 165 species in SSF, 151 species in MOF, and 179 species in DOF. The Sorenson and Morisita-Horn indexes were similar between the two seasons in the three forest types (Tab. I). In both MOF and DOF species richness and abundance recorded per point count were significantly higher in breeding than in non-breeding season (Tab. II, Mann-Whitney, $\mathrm{p}<0.01$ ); for the SSF the difference between the seasons was not significant.

Considering all sampling areas and seasons, we recorded 46 frugivores, 105 insectivores, and 86 omnivores. In all unctional bird groups, both Sorenson and Morisita-Horn indexes were similar between the two seasons (Tab. I). Paired compari-

Table I. Sorenson and Morisita-Horn indexes of breeding and nonbreeding season similarities for all species and functional bird groups in semi-deciduous forest (SSF), mixed ombrophilous forest (MOF), and dense ombrophilous forest (DOF).

\begin{tabular}{lcccc}
\hline Forest types & All species & Frugivores & Insectivores & Omnivores \\
\hline $\begin{array}{l}\text { Sorenson } \\
\text { SSF }\end{array}$ & 0.82 & 0.85 & 0.77 & 0.86 \\
MOF & 0.87 & 0.84 & 0.85 & 0.87 \\
DOF & 0.78 & 0.78 & 0.85 & 0.67 \\
Morisita-Horn & & & & \\
SSF & 0.96 & 0.95 & 0.98 & 0.96 \\
MOF & 0.86 & 0.89 & 0.91 & 0.80 \\
DOF & 0.83 & 0.74 & 0.84 & 0.88 \\
\hline
\end{tabular}


sons of seasons showed that richness and abundance recorded per point count of omnivores were significantly higher in breeding than in non-breeding season in almost all forest types; only in DOF the abundance of omnivores did not show a significant difference. For insectivores, only in DOF did we find a significant difference in species richness while richness and abundance did not vary among seasons in the other habitats. For frugivores, only in DOF a significant difference in abundance was found, while in the other habitats no significant seasonal differences in richness or abundance were detected (Tab. II).

\section{DISCUSSION}

Our results indicate that species composition and contacts numbers were similar between the seasons, indicating that most of the bird species recorded in the breeding season was also present during the non-breeding season. However, MOF and DOF showed decrease on bird species and abundance per point count in the non-breeding season; in SSF these results were not significantly different between seasons. The lower frequency of birds vocalization during the non-breading season is considered one reason for the low probability of record them during this season (van Heezik \& Seddon 1999, Pagen et al. 2002), besides the seasonal modification in habitat use and in functional groups (Blendinger 2005, Bowen et al. 2007, Lopez de Casenave et al. 2008). Considering this, changes in the detection of bird species using the point count during non-breeding season would be expected also in SSF (ANTUNES 2008). This suggests that other factors seem to have influenced the obtained results in this forest type, like regular distribution of food during the year and changing of behavior (e.g. multispecific flock formation) (Develey \& Peres 2000, ANJos 2002). ANJos et al. (2007) observed also an increase in richness and abundance of birds due slope area of riparian forest in seasonal semi-deciduous forest.

Omnivorous birds showed higher differences in richness and abundance recording between the seasons in all forest sites when compared to frugivores and insectivores. The plasticity on resources used by omnivores may have influenced this result: wide habitat dispersal could have been an important factor for the decreasing probabilities of omnivorous birds recording during non-breeding season in the present study (CATTERALL et al. 1998, van Heezik \& Seddon 1999, Blendinger 2005, Moorman et al. 2007, Lopez de Casenave et al. 2008).

Richness and abundance of frugivores and insectivores did not exhibit notable differences between seasons in the study sites. ANjos (2002) suggested that food supply seems to be higher and better distributed during the year in SSF, including the non-breeding season, which would benefit such frugivores guild. MOORMAN et al. (2007) found that insectivorous birds from bottomland forest exhibited few seasonal changes in using arthropods as food resource. This may suggest that food resources for these guilds were sufficiently abundant throughout the year in these forest types. However, several factors, like mixed species foraging flocks of insectivores (DEVELY \& Peres 2000) and flock formation of some frugivores (e.g. Psittacidae species) may have improved the de-

Table II. Median values (range 25-75 quartiles) of number of species (richness) and of contacts (abundance) per point count in the breeding (breed) and non-breeding (Nbreed) seasons in seasonal semi-deciduous forest (SSF), mixed ombrophilous forest (MOF), and dense ombrophilous forest (DOF). ${ }^{1}$ Pairwise comparisons using Mann-Whitney test (U).

\begin{tabular}{|c|c|c|c|c|c|c|}
\hline & \multicolumn{2}{|c|}{ Richness } & \multirow{2}{*}{$\frac{\text { Test }^{1}}{\mathrm{U}}$} & \multicolumn{2}{|c|}{ Abundance } & \multirow{2}{*}{$\begin{array}{c}\text { Test }^{1} \\
\mathrm{U}\end{array}$} \\
\hline & Breed & Nbreed & & Breed & Nbreed & \\
\hline \multicolumn{7}{|l|}{ All species } \\
\hline SSF & $16(12-23)$ & 15 (8.5-19) & $3940.0 \mathrm{~ns}$ & $20(14-27)$ & $19(11-25.5)$ & $4117.5 \mathrm{~ns}$ \\
\hline MOF & $18(14-21)$ & $16(11-19.5)$ & $5213.5^{*}$ & $24(18.5-28)$ & $19(13-26)$ & $5306.0^{*}$ \\
\hline DOF & $19(16-22.5)$ & $16(12-18)$ & $1347.0^{*}$ & $22(20-26.5)$ & $18(13.5-22)$ & $1362.0^{*}$ \\
\hline \multicolumn{7}{|l|}{ Frugivores } \\
\hline SSF & $3(1-4)$ & $2(1-4)$ & $3954.5 \mathrm{~ns}$ & $3(1-5)$ & $2(1-4)$ & $3963.5 \mathrm{~ns}$ \\
\hline MOF & $1(0-2)$ & $1(0-1)$ & $6528.0 \mathrm{~ns}$ & $1(0-2)$ & $1(0-1.5)$ & $6482.0 \mathrm{~ns}$ \\
\hline DOF & $3(2-4)$ & $3(2-4)$ & $2285.5 \mathrm{~ns}$ & $4(3-5)$ & $3(2-4)$ & $2074.0^{* *}$ \\
\hline \multicolumn{7}{|c|}{ Insectivores } \\
\hline SSF & $7(4.5-9)$ & $6(4-9)$ & $4514.0 \mathrm{~ns}$ & $8(5-11)$ & $8(5-12)$ & $4449.0 \mathrm{~ns}$ \\
\hline MOF & $9.5(7-12)$ & $8(6-12)$ & $6557.5 \mathrm{~ns}$ & $12(8-15)$ & $10.5(8-14.5)$ & $6657.5 \mathrm{~ns}$ \\
\hline DOF & $8(5-10)$ & $5(4-7)$ & $1691.0^{*}$ & $11(8-14)$ & $10(7-14)$ & $2374.0 \mathrm{~ns}$ \\
\hline \multicolumn{7}{|c|}{ Omnivores } \\
\hline SSF & $6(4-9)$ & $5(3-8)$ & $3655.5^{\star *}$ & $9(5-12)$ & $6(4-10.5)$ & $3743.5^{* *}$ \\
\hline MOF & $7(5.5-9)$ & $5(3-7)$ & $4228.0^{*}$ & $9(6-11)$ & $7(5-9)$ & $5611.0 *$ \\
\hline DOF & $7(6-9)$ & $5(4-6.5)$ & $1268.0^{*}$ & $10(6-12.5)$ & $9(5-12.5)$ & $2305.0 \mathrm{~ns}$ \\
\hline
\end{tabular}

${ }^{*} \mathrm{p}<0.001 ;{ }^{* *} \mathrm{p}<0,01 ;$ ns: no difference significant. 
tectability of these guilds in non-breeding season, once this association often occurs. Specifically in DOF, frugivores presented significant differences in abundance comparing the seasons, what could be attributed to a local migration (altitudinal) (SICK 1997, IsLER \& ISLER 1999). In the same forest type, insectivores presented significant differences in richness when the seasons were compared, but without clear reasons.

Based on the results of the present study, bird communities vary among forest types and functional groups. This suggests that the use of point counts for bird sampling in these three types of forest in the southern portion of the Brazilian Atlantic forest should be adjusted: the field method could be concentrated during the breeding season (Spring and Summer), even in SSF sites, what would reduce the probability of underestimate local richness and species abundance, mainly of omnivorous birds. This procedure is useful once it can reduce the time spent in collecting field data. Anjos (2007) observed that a sampling period of only four days was enough to record $90 \%$ of bird species in a SSF area during the breeding season.

\section{ACKNOWLEDGEMENTS}

The financial support for this study was provided by CNPq, Brazil through the Mata Atlântica Program (690146/01-9) that also provide DTI grant during field work to authors G.H. Volpato, E.V. Lopes, L.B. Mendonça, R. Boçon, M.V. Bisheimeir, P.P. Serafini. The first author also acknowledges actual grant at CAPES. Luiz dos Anjos, L.B. Mendonça and E.V. Lopes has grant from CNPq (453342/2006-0, 140317/2006-6 and 140353/2006-2, respectively). Instituto Brasileiro do Meio Ambiente e dos Recursos Naturais Renováveis, Instituto Ambiental do Paraná, Sociedade de Pesquisa em Vida Selvagem e Educação Ambiental, Indústria Klabin de Papel e Celulose, Paróquia Nossa Senhora das Neves (Palmeira, PR), Fazenda Hotel Serra do Panelão (Urubici, SC), and Pousada Rio Canoas (Urubici), gave researching permissions and logistical facilities during field work.

\section{LITERATURE CITED}

Anjos, L. 2002. Forest bird communities in the Tibagi river hydrographic basin, southern Brazil. Ecotropica 8: 67-79.

Anjos, L. 2007. A eficiência do método de amostragem por pontos de escuta na avaliação da riqueza de aves. Ararajuba 15: 239-243.

Anjos, L.; G.H. Volpato; E.V. Lopes; P.P. Serafini; F. Poletto \& A. AleIXo. 2007. The importance of riparian forest for maintenance of bird species ricnhess in an Atlantic Forest remnant, southern Brazil. Revista Brasileira de Zoologia 24: 10781086.

Antunes, A.Z. 2008. Diurnal and seasonal variability in bird counts in a forest fragment in southeastern Brazil. Revista Brasileira de Zoologia 25: 228-237.

BART, J. \& S.L.EARNst. 2002. Double sampling to estimate density and population trends in birds. Auk 119: 36-45.
Betts, M.G.; P.P. Neal; J. Simon \& J. Nocera. 2005. Point count summary statistics differentially predict reproductive activity in bird-habitat relationship studies. Journal of Ornithology 146: 151-159.

Bibby, C.; N.D. Burguess \& D.A. HiLl. 1992. Bird Census Techniques. London, Academic Press, 257p.

Blendinger, P.G. 2005. Abundance and diversity of small-bird assemblage in the Monte desert, Argentina. Journal of Arid Environments 61: 567-587.

Blondel, J.; C. Ferry \& B. Frochot. 1970. La méthode des indices ponctuels d'abondance (I.P.A.) ou des relevés d'avifaune par "stations d'écoute". Alauda 38: 55-71.

Bowen, L.T.; C.E. Moorman \& J.C. Kilgo. 2007. Seasonal bird use of canopy gaps in a bottomland Forest. The Wilson Journal of Ornithology 119: 77-88.

Catterall, C.P.; M.B. Kingston; K. Park \& S. Sewell. 1998. Deforestation, urbanization and seasonality: interacting effects on a regional bird assemblage. Biological Conservation 84: 65-81.

Develey, P.F. \& C.A. Peres. 2000. Resource seasonality and the structure of mixed species bird flocks in a coastal Atlantic forest of southeastern Brazil. Journal of Tropical Ecology 16: 33-53.

Hutto, R.L.; M. Pletschet \& P. Hendricks. 1986. A fixed-radius point count method for nonbreeding and breeding season use. Auk 103: 593-602.

Isler, M.L. \& P.R. Isler. 1999. The tanagers. Natural history, distribution, and identification. Washington, Smithsonian Institution Press, 406p.

IONGH, H.H. \& M. VAN WEERD. 2006. The use of avian guilds for the monitoring of tropical forest disturbance by logging. Wageningen, Tropenbos Documents 17. Available online at: http://www.tropenbos.nl/files/Iongh_Weerd_bird_ indicators.pdf. [Access: 12/I/2007].

Lopez de Casenave, J.L.; V.R. Cueto \& L. Marone. 2008. Seasonal dynamics of guild structure in a bird assemblage of the central Mont desert. Basic of Applied and Ecology 9: 78-90.

Magurran, A.E. 1988. Ecological diversity and its measurement. Princeton, Princeton University Press, 179p.

Moorman, C.E.; L.T. Bowen; J.C. Kilgo; C.E. Sorenson; J.L. Hanula; S.HoRn \& M.D. Ulyshen. 2007. Seasonal diets of insectivorous birds using canopy gaps in a bottomland forest. Journal of Field Ornithology 78: 11-20.

Oliveira-Filho, A.T. \& M.A.L. Fontes. 2000. Patterns of Floristic Differentiation among Atlantic Forests in Southeastern Brazil and the Influence of Climate. Biotropica 32: 793-810.

Pagen, R.W.; F.R. Thompson III \& D.E. Burhans. 2002. A comparison of point-count and mist-net detections of $\mathrm{f}$ songbirds by habitat and time-of-season. Journal of Field Ornithology 73: 53-59.

Rosenstock, S.S.; D.R. Anderson; K.M. Giesen; T. Leukering \& M.F. Cartes. 2002. Landbird counting techniques: Current practices and an alternative. Auk 119: 46-53. 
SICK, H. 1997. Ornitologia Brasileira. Rio de Janeiro, Editora Nova Fronteira, 912p.

Thompson, W.L. 2002. Towards reliable bird surveys: accounting for individuals present but not detected. Auk 119: 18-25.

VAN HeEzIK, Y. \& P.J. Seddon. 1999. Effects of season and habitat on bird abundance and diversity in a steppe desert, northern
Saudi Arabia. Journal of Arid Environments 43: 301-317.

Whitman, A.A.; J.M. Hagan \& N.V.L. BrokaW. 1997. A comparison of two bird survey techniques used in a subtropical forest. Condor 99: 955-965.

ZAR, J.H. 1999. Biostatistical analysis. New Jersey, PrenticeHall, 786p.

Submitted: 19.V.2008; Accepted: 09.III.2009.

Editorial responsibility: Fernando de Camargo Passos. 